\title{
Theoretical study about L-arginine complexes formation with thiotriazolin
}

\author{
L. I. Kucherenko ${ }^{1,2}$, 0. V. Hromyleva ${ }^{1}$, I. A. Mazur ${ }^{1,2}$, S. V. Shishkina ${ }^{2}$ \\ ${ }^{1}$ Zaporizhzhia State Medical University, Ukraine, ${ }^{2}$ SPA «Farmatron», Zaporizhzhia, Ukraine
}

Key words:

L-arginine,

thiotriazolin, quantum-chemical

calculations,

molecular

complexes.

\section{Zaporozhye}

medical journal

2017; 19 (1),

108-112

DOI:

10.14739/2310-1210.

2017.1.91736

E-mail:

hromyleva.olga@

gmail.com
Brain vascular diseases are one of the leading causes of morbidity, mortality and disability of population in the industrialized countries of the world. An important element of this problem's solution is the creation of new highly effective and safe drugs, which would lead to mortality reduction, to increase in life expectancy and quality of life. Therefore it is interesting to create a new combined drug based on L-arginine and thiotriazolin.

The aim of the study: to consider the possible structure and energy characteristics of complexes formed by L-arginine, 3-methyl-1,2,4-triazolyl-5-thioacetate (MTTA) and morpholine.

Calculation method. The initial approximation to the complex geometry was obtained using molecular docking with the help of AutoDock Vina program. The obtained ternary complexes were pre-optimized by semi-empirical PM7 method with modeling the impact of the environment by COSMO method. The calculations were carried out using MOPAC2012 program. Then they were optimized by B97-D3/SVP + COSMO (Water) dispersion-corrected DFT-D with geometrical spreading correction on insufficiency of $\mathrm{gCP}$ basis set. A more accurate calculation of the solvation energy was conducted by SMD. The calculations by density functional method were carried out using the ORCA 3.0.3 software. Energy complex formation in solution was calculated as the difference of the Gibbs free energy of the solvated complex and its individual components.

Results. Quantum chemical calculations show, that thiotriazolin and L-arginine are able to form ternary complexes, where molecules are linked by multiple hydrogen bonds. The calculation data suggest, that studied complexes are thermodynamically unstable in solution. The energies of them are positive, but rather low despite charge gain of a number of intermolecular hydrogen bonds.

Finding. Based on the results of the conducted quantum-chemical study of a three components system (MTTA, morpholine, and L-arginine) it is possible to show the possibility to form ternary complexes with low stability in infinite dilute solutions. It should be noted that two negative charges are always localized in formed complexes on the deprotonated carboxyl groups. The positive charges are located either on the guanidine moiety and the $\alpha$-amino group of L-arginine, or on the guanidine moiety of L-arginine and protonated molecule of morpholine. It can be expected that the strengthening of intermolecular interactions in the real solutions may result in increased stability of the complexes.

\section{Киючові слова:}

L-аргінін, тіотриазолін, квантово-хімічні розрахунки, молекулярні комплекси.

\section{Запорізький} медичний

журнал. - 2017. -

T. 19, № 1(100). -

C. 108-112

\section{Теоретичне дослідження можиивості утворення комплексів L-аргініну з тіотриазоліном}

\section{А. І. Кучеренко, О. В. Хромильова, І. А. Мазур, С. В. Шишкіна}

Судинні захворювання головного мозку - одна з головних причин захворюваності, смертності та інвалідизації населення промислово розвинених країн світу. Важливий елемент вирішення цієї комплексної проблеми - створення нових високоефективних і безпечних лікарських препаратів, застосування яких призводило б до зниження смертності, поліпшення якості та тривалості життя. Тому викликає інтерес створення нового комбінованого препарату на основі L-аргініну з тіотриазоліном.

Мета роботи - розглянути можливу структуру та енергетичні характеристики комплексів, що утворені L-аргініном, 3-метил-1,2,4-триазоліл-5-тіоацетатом (МТТА) та морфоліном.

Методика розрахунків. Початкове наближення до геометрії комплексів отримано, використовуючи процедуру молекулярного докінгу за допомогою програми AutoDock Vina. Отримані трикомпонентні комплекси були попередньо оптимізовані напівемпіричним методом PM7 із моделюванням впливу середовища методом COSMO. Розрахунки здійснили за допомогою програми МОРАС2012. Потім комплекси були оптимізовані методом функціонала щільності з емпіричною дисперсійною поправкою B97-D3/SVP + COSMO (Water) із застосуванням геометричної поправки на неповноту базисного набору gCP. Більш точний розрахунок енергії сольватації виконаний методом SMD. Розрахунки методом фуункціонала щільності проведені за допомогою програми ORCA 3.0.3. Енергія утворення комплексів у розчині розраховувалася як різниця вільних енергій Гіббса сольватованого комплексу та сольватованих окремих його компонент.

Результати. Квантово-хімічні розрахунки показують, що тіатріазолін і L-аргінін здатні утворювати трикомпонентні комплекси, молекули в яких пов'язані шляхом множинних водневих зв'язків. Результати розрахунків дають змогу припустити, що вивчені комплекси термодинамічно нестабільні в розчині. Енергії утворення комплексів позитивні, але доволі низькі, незважаючи на зарядове посилення ряду водневих зв'язків.

Висновки. Квантово-хімічні дослідження системи, що складається з трьох компонент (MTTA, морфолин i L-аргінін), показали можливість утворення трикомпонентних комплексів із невисокою стабільністю в нескінченно розведених розчинах. Варто відзначити, що в утворених комплексах два негативних заряди завжди локалізовані на депротонованих карбоксильних групах. Позитивні заряди локалізовані або на гуанідиновому фррагменті та $\alpha$-аминогруппі L-аргініну, або на гуанідиновому фррагменті L-аргініну та протонованій молекулі морфоліну. Можна очікувати, що в реальних розчинах посилення міжмолекулярних взаємодій може призвести до збільшення стабільності комплексів. 


\title{
Теоретическое исследование возможности образования комплексов L-аргинина с тиотриазолином
}

\begin{abstract}
А. И. Кучеренко, О. В. Хромылёва, И. А. Мазур, С. В. Шишкина
Сосудистые заболевания головного мозга - одна из основных причин заболеваемости, смертности и инвалидизации населения промышленно развитых стран мира. Важным элементом решения данной комплексной проблемы, является создание новых высокоэффрективных и безопасных лекарственных препаратов, применение которых приводило бы к снижению смертности, улучшению качества и продолжительности жизни. Поэтому вызывает интерес создание нового комбинированного препарата на основе L-аргинина с тиотриазолином.
\end{abstract}

Цель работы - рассмотреть возможную структуру и энергетические характеристики комплексов, образованных L-аргинином, 3-метил-1,2,4-триазолил-5-тиоацетатом (МТТА) и морфолином.

Методика расчётов. Исходное приближение к геометрии комплексов получили, используя процедуру молекулярного докинга с помощью программы AutoDock Vina. Полученные трёхкомпонентные комплексы были предварительно оптимизированы полуэмпирическим методом PM7 с моделированием влияния среды методом COSMO. Расчёты проводились с помощью программы МОРАС2012. Затем комплексы были оптимизированы методом функционала плотности с эмпирической дисперсионной поправкой B97-D3/SVP + COSMO (Water) с применением геометрической поправки на неполноту базисного набора gCP. Более точный расчёт энергии сольватации был проведён методом SMD. Расчёты методом функционала плотности проведены с помощью программы ORCA 3.0.3. Энергия образования комплексов в растворе рассчитывалась как разница свободных энергий Гиббса сольватированного комплекса и сольватированных отдельных его компонент.

Результаты. Квантово-химические расчёты показывают, что тиатриазолин и L-аргинин способны образовывать трёхкомпонентные комплексы, молекулы в которых связаны за счёт множественных водородных связей. Результаты расчётов позволяют предположить, что изученные комплексы термодинамически нестабильны в растворе. Энергии образования комплексов положительные, но достаточно низкие, несмотря на зарядовое усиление ряда межмолекулярных водородных связей.

Выводы. Проведённое квантово-химическое исследование системы, состоящей из трёх компонент (МТТА, морфолин и L-аргинин) показало возможность образования трёхкомпонентных комплексов с невысокой стабильностью в бесконечно разбавленных растворах. Стоит отметить, что в образованных комплексах два отрицательных заряда всегда локализованы на депротонированных карбоксильных группах. Положительные заряды локализованы либо на гуанидиновом фрагменте и a-аминогруппе L-аргинина, либо на гуанидиновом фрагменте L-аргинина и протонированной молекуле морфолина. Можно ожидать, что в реальных растворах усиление межмолекулярных взаимодействий может привести к увеличению стабильности комплексов.

Brain vascular diseases are one of the leading causes of morbidity, mortality and disability of population in the industrialized countries of the world. Every year, about 6 million people suffer from stroke, 4.7 million of them die. Despite constant efforts to optimize the treatment of diseases of central nervous and cardiovascular systems, the problem remains unresolved. An important element of this problem's solution is the creation of new highly effective and safe drugs, which would lead to mortality reduction, to increase in life expectancy and quality of life [1]. Therefore, the development of neurometabolitetropic cerebroprotectors is an actual problem of nowadays pharmacy and medicine. In current times, the neurotransmitter amino acids are used increasingly for the correction and regulation of neurological conditions in stroke patients. Neurotransmitter amino acids manage the major body functions, including movement, emotional response, and physical ability to experience pleasure and pain. The most known neurotransmitter amino acids affecting mood regulation are arginine, glycine, taurine, tryptophan, lysine, glutamic acid, etc.

The creation of product based on fixed combination of active ingredient with anti-oxidants is one of the most promising approaches in the development of new drugs. Thiotriazolin is one of the well-known antioxidants. Thiotriazolin has such wide range of pharmacological effects as antioxidant, membrane stabilizing, anti-ischemic, antiarrhythmic, immunomodulatory, anti-inflammatory, hepatoprotective, cardioprotective. Therefore it is interesting to create a new combined preparation based on L-arginine (1) and thiotriazolin (2).
The combined use of L-arginine with Thiotriazolin creates the question of the possibility of forming sufficiently stable intermolecular complexes.

\section{Purpose of the study}

To consider the possible structure and energy characteristics of complexes formed by L-arginine, 3-methyl-1,2,4-triazolyl-5-thioacetate (MTTA) and morpholine.

\section{Calculation method}

The similar technique, which has been used previously in studies of thiotriazolin-isoniazid complexes, was also used to simulate the structure and stability of L-arginine+Thiotriazolin complexes [2].

The initial approximation to the complex geometry was obtained using molecular docking with the help

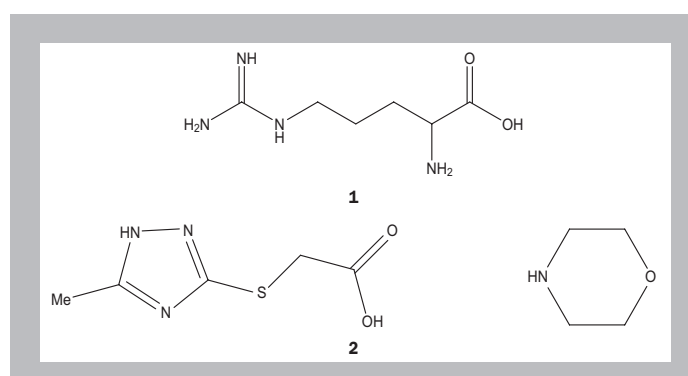

Fig. 1. The molecules, that make up the studied complexes.
Киючевые слова:

L-аргинин,

тиотриазолин, квантовохимические расчёты, молекулярные комплексы.

\section{Запорожский} медицинский журнал. - 2017. T. 19, № 1(100). -

C. 108-112 


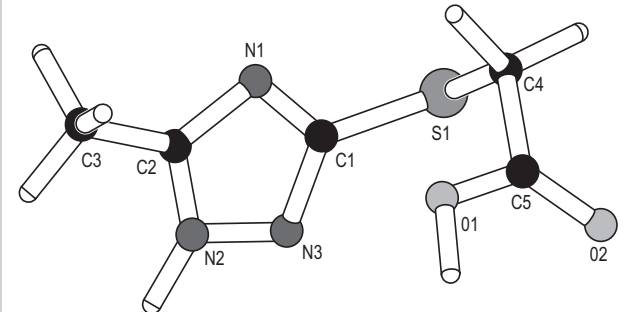

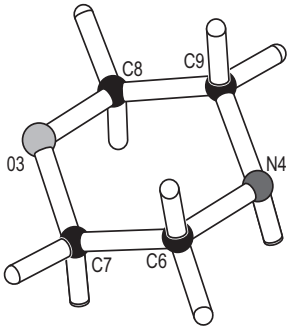

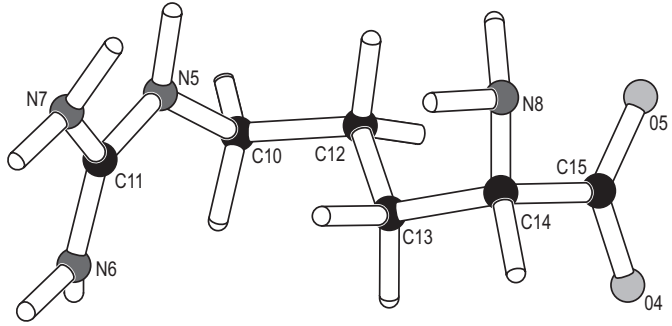

C

Fig. 2. The structure of the thiatriazolin $(a-b)$ and arginine (c) molecules with the numbering of the atoms according to quantum chemical calculations.

Table 1. The structure of the most stable thiotriazolin+arginine complexes, their energy of formation ( $\Delta \mathrm{G}^{298}$ form $\mathrm{kcal} / \mathrm{mol}$ ) and the characteristics of hydrogen bonds (H...A, A and DH...A, deg.) According to B97-D3/TZVP + SMD (Water) method

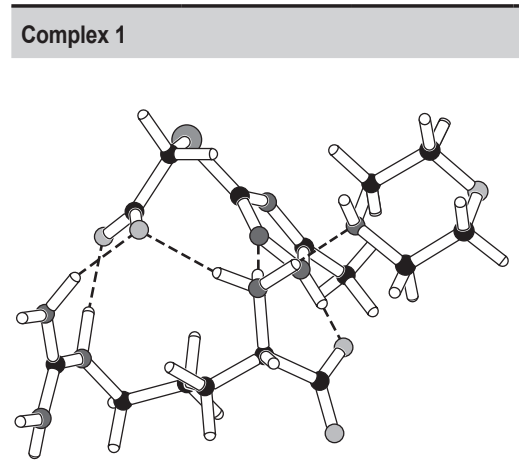

Complex 2

\section{$\Delta \mathrm{G}_{\text {form }}^{298}=2.0 \mathrm{kcal} / \mathrm{mol}$}

\begin{tabular}{llllll} 
N2-H...O5 & 1.71 & 159 & N4-H...O2 & 2.13 & 166 \\
N5-H...N4 & 1.69 & 173 & N7-H...O1 & 1.82 & 173 \\
N5-H...01 & 2.04 & 147 & N5-H...O2 & 1.78 & 176 \\
N5-H...N1 & 1.88 & 170 & N8-H...O2 & 1.78 & 171 \\
N8-H...01 & 1.84 & 165 & N8-H...O5 & 1.89 & 121 \\
N6-H...O2 & 1.77 & 177 & N8-H...N3 & 1.94 & 150 \\
\hline Complex 3 & & Complex 4
\end{tabular}

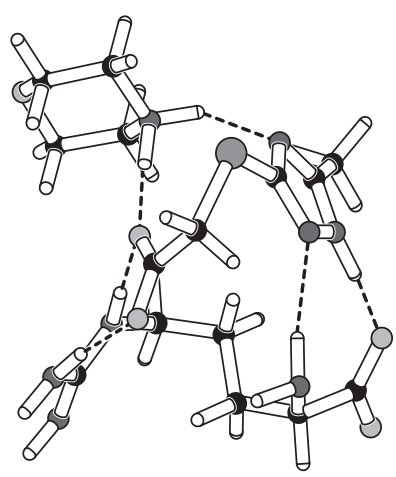

$\Delta \mathrm{G}_{\text {form }}^{298}=4.5 \mathrm{kcal} / \mathrm{mol}$

\begin{tabular}{llllll} 
N2-H...O5 & 1.56 & 177 & N2-H...O5 & 1.84 & 152 \\
N4-H...O2 & 1.67 & 167 & N4-H...O1 & 2.22 & 167 \\
N4-H...N3 & 1.87 & 149 & N7-H...N1 & 1.89 & 169 \\
N7-H...O1 & 1.81 & 170 & N5-H...O1 & 1.76 & 165 \\
N5-H...O2 & 1.79 & 177 & N8-H...O1 & 1.64 & 172 \\
N8-H...N1 & 2.26 & 169 & N8-H...O5 & 1.99 & 119 \\
N2-H...O5 & 1.56 & 177 & N2-H...O5 & 1.84 & 152 \\
\hline
\end{tabular}

of AutoDock Vina program [3]. On the first stage we carried out the docking of MTTA and morpholine to construct ternary complexes, which resulted in selected 50 the most stable complexes. Further, we carried out the docking of obtained MCTA complexes and morpholine with L-arginine, and also we selected 50 most stable complexes. Thus, 2500 of initial geometry was obtained for each of the ternary complexes. This procedure was carried out for each of the possible tautomeric forms of ternary complexes.

On the second stage the obtained ternary complexes were pre-optimized by semi-empirical PM7 method with modeling the impact of the environment by COSMO method. The calculations were carried out using MOPAC2012 program [4]. According to calculations, 100 of the most low-lying energy structures were selected for each of the complexes. Then they were optimized by B97-D3/SVP + COSMO (Water) dispersion-corrected DFT-D [5-9] with geometrical spreading correction on insufficiency of $\mathrm{gCP}$ basis set [7]. 10 structures of ternary complexes with the lowest energy were selected, for which the final calculation of geometry and thermodynamic parameters in the approximation of rigid rotor by B97-D3/TZVP + COSMO method, was held. A more accurate calculation of the solvation energy was conducted by SMD [8]. The calculations by density functional method were carried out using the ORCA 3.0.3 software [9]. Energy complex formation in solution was calculated as the difference of the Gibbs free energy of the solvated complex and its individual components.

With a high degree of certainty, the selected method, which is based on a study of the full conformational space of complexes by molecular docking methods and by series of successive quantum chemical calculations with the use of increasingly methods, guarantees the most stable ternary complexes.

\section{Results and discussion}

Earlier studies of thiotriazolin [10] showed that the MTTA is easily deprotonated into organic anion, and morpholine, respectively, becoming a cation, attaching a hydrogen atom. Thus, the compound of morpholine and MTTA is an organic salt. On the other hand, L-arginine, as the amino acid, has to exist in the form of zwitter-ion. However, unlike many other amino acids, L-arginine molecule contains three hydrogen atoms, which may be protonated (Fig. 1). Therewith, the $\mathrm{L}$-arginine zwitterionic form acts as both donor and acceptor in the formation of intermolecular hydrogen bonds reinforced 
with morpholine cation and MTTA anion. This suggests the possibility of both two-component complexes with L-arginine and Thiotriazolin and one of the components and the ternary complexes, involving all three molecules. The multiplicity of donor and acceptor sites in all three studied molecules (Fig. 2) creates the possibility of the formation of sufficiently large number of possible complexes.

Quantum chemical calculations show that thiotriazolin and L-arginine are able to form ternary complexes, where molecules are linked by multiple hydrogen bonds. From 5 to 7 intermolecular hydrogen bonds are formed in the most stable complexes (Table 1). In this case, each of the molecules forms hydrogen bonds with the other two in complexes.

The analysis of 10 most stable complexes showed that they can be divided into two groups. In one group (complexes 1, 2, 4, 7, 9, 10) morpholine molecule is neutral, and $\mathrm{L}$-arginine molecule contains two protonated nitrogen atoms, whereby its charge is +2 . In second group (complexes 3 , $5,6,8)$ morpholine molecule is protonated at the nitrogen atom and is a cation, as well as L-arginine molecule with one protonated nitrogen atom. Negative charges in all calculated complexes were localized at the carboxyl groups of L-arginine and MTTA. It should be also noted that imino group of guanidine moiety is protonated in the L-arginine molecule in all cases, whereas the a-aminogroup may be either protonated or neutral.

The comparison of intermolecular hydrogen bonds in two most stable complexes showed that nitrogen atom of neutral morpholine molecules may act as acceptor (complex 1) and donor (complex 2) of proton. At the same time, as the proton donor, neutral morpholine molecule forms hydrogen bonds, and their characteristics are very close to the hydrogen bonds formed by protonated morpholine. As the proton acceptor, morpholin forms weaker intermolecular hydrogen bonds.

The calculation data suggest that studied complexes are thermodynamically unstable in solution. The energies of them are positive, but rather low (Table 1) despite charge gain of a number of intermolecular hydrogen bonds. Apparently, this is due to the high conformational flexibility of the molecules, in which the involved hydrogen bonding groups are separated by a bridge containing several methylene groups, and quite easy transfer of protons involved in hydrogen bonding. It is also possible to affirm the existence of some of the most profitable mode binding in complexes.

It should be noted that the solvation energies were calculated in the approximation of infinite dilution. Molecular complexes are expected to be more stable in the final concentration of solution due to strengthening of intermolecular interactions.

\section{Findings}

1. Based on the results of the conducted quantum-chemical study of a three components system (MTTA, morpholine, and L-arginine) it is possible to show the possibility to form ternary complexes with low stability in infinite dilute solutions.

2. It should be noted that two negative charges are always localized in formed complexes on the deprotonated carboxyl groups. The positive charges are located either on the guanidine moiety and the a-amino group of L-arginine, or on the guanidine moiety of L-arginine and protonated molecule of morpholine.
Table 1. The structure of the most stable thiotriazolin+arginine complexes, their energy of formation $\left(\Delta G^{298} \mathrm{kcolm} / \mathrm{mol}\right)$ and the characteristics of hydrogen bonds (H...A, $A$ and DH...A, deg.) According to B97-D3/TZVP + SMD (Water) method
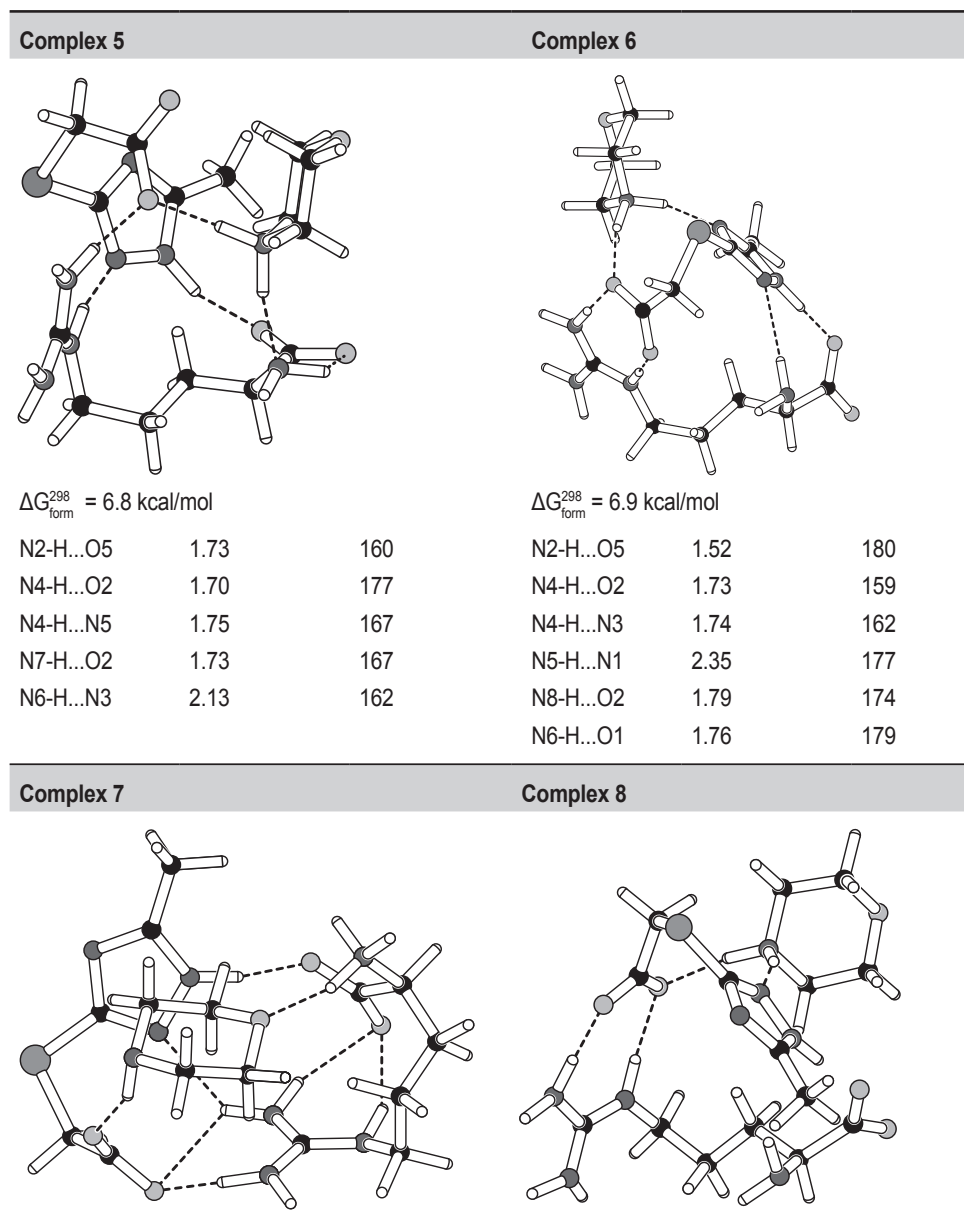

$\Delta \mathrm{G}_{\mathrm{form}}^{298}=8.3 \mathrm{kcal} / \mathrm{mol}$

\begin{tabular}{lll} 
N2-H...O5 & 1.77 & 160 \\
N4-H...O2 & 2.11 & 153 \\
N5-H...O4 & 1.90 & 146 \\
N6-H...O1 & 1.67 & 164 \\
N7-H...O4 & 2.24 & 137 \\
N7-H...N1 & 2.26 & 138 \\
N8-H...O3 & 1.80 & 161 \\
\hline
\end{tabular}

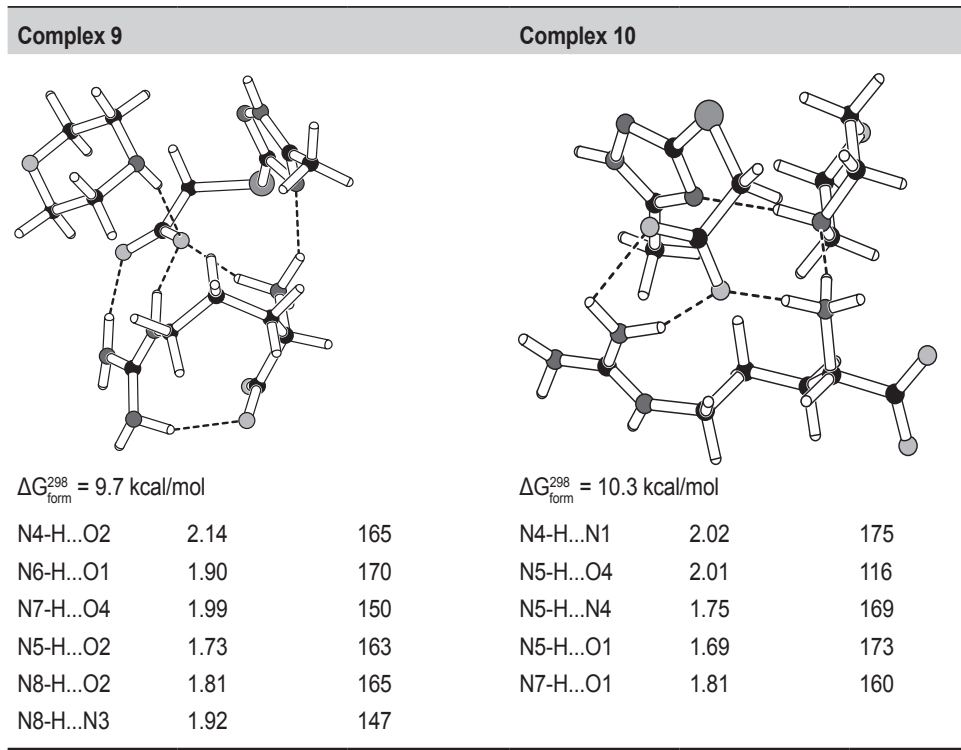


3. It can be expected that the strengthening of intermolecular interactions in the real solutions may result in increased stability of the complexes.

\section{References}

[1] Belenichev, I. F., Chornyi, V. I., Nahornaia, E.A., Pavlov, S. V., Chornyi, T. V., Bukhtyiarova, N. V., et al. (2015) Nejroprotekciya i nejroplastychnost [Neuroprotection and neuroplasticity]. Kyiv: Lohos. [in Ukrainian].

[2] Zubatyuk, R. I., Kucherenko, L. I., Mazur, I. A., Khromyleva, O. V., \& Shyshkin, O. V. (2014). Teoreticheskoe isledovanie stroeniya kompleksov izoniazida s tiotriazolinom [Theoretical study of the structure of complexes with isoniazid Thiotriazoline]. Himiya geterociklicheskikh soedinenij, 3, 476-482. [in Latvia].

[3] Trott, O., \& Olson, A. J. (2010) Software news and update AutoDock Vina: Improving the speed and accuracy of docking with a new scoring function, efficient optimization, and multithreading. J. Comput. Chem, 31, 455-461. doi: 10.1002/jcc.21334.

[4] Stewart, J. J. P. MOPAC2012, (2012) Colorado Springs, CO: Stewart Computational Chemistry, USA.

[5] Grimme, S., Antony, J., Ehrlich, S., \& Krieg, H. (2010) A consistent and accurate ab initio parametrization of density functional dispersion correction (DFT-D) for the 94 elements H-Pu. J. Chem. Phys., 132 154104. doi: $10.1063 / 1.3382344$.

[6] Grimme, S., Ehrlich, S., \& Goerigk, L. (2011) Effect of the damping function in dispersion corrected density functional theory. J. Comput. Chem, 32, 1456-1465. doi: 10.1002/jcc.21759.

[7] Kruse, H., \& Grimme, S. (2012) A geometrical correction for the inter- and intra-molecular basis set superposition error in Hartree-Fock and density functional theory calculations for large systems. J. Chem. Phys., 136, 154101. doi: $10.1063 / 1.3700154$

[8] Marenich, A. V., Cramer, C. J., \& Truhlar, D. G. (2009) Universal solvation model based on solute electron density and on a continuum model of the solvent defined by the bulk dielectric constant and atomic surface tensions. J. Phys. Chem., 113, 6378-6396. doi: 10.1021/jp810292n.

[9] Neese, F. (2012) The ORCA program system. Wiley Interdiscip. Rev. Comput. Mol. Sci., 2, 73-78. doi: 10.1002/wcms.81.

[10] Shishkina, S. V., Zubatyuk, R. I., Kucherenko, L. I., Mazur, I. A., \& Shishkin O. V. (2009) Two polymorphs of morpholin-4-ium 2-(5-methyl-1H-1,2,4-triazol-3-ylsulfanyl)acetate Acta Crystallographica Section, C65, 024-026.

\section{Information about authors:}

Kucherenko L. I., Dr.hab., Professor, Head of the Department of Pharmaceutical Chemistry, Zaporizhzhia State Medical University, Vice-President of SPA “Farmatron”, Zaporizhzhia, Ukraine.

Hromyleva O. V., PhD, Senior Lecturer of the Department of Pharmaceutical Chemistry, Zaporizhzhia State Medical University, Ukraine.

Mazur I. A., Dr.hab., Zaporizhzhia State Medical University, Professor of the Department of Pharmaceutical Chemistry, Zaporizhzhia State Medical University, President of SPA "Farmatron", Zaporizhzhia, Ukraine.

Shishkina S. V., Ph.D., analyst at SPA “Farmatron”, Zaporizhzhia, Ukraine.

\section{Відомості про авторів:}

Кучеренко А. І., А-р фарм. наук, професор, зав. каф. фармацевтичної хімії, Запорізький державний медичний університет, віце-президент НВО «Фарматрон", Запоріжжя, Україна.

Хромильова О. В., канА. Фарм. наук, старший викладач каф. фармацевтичної хімії, Запорізький державний медичний університет, Україна.

Мазур І. А., А-р фарм. наук, професор каф. фармацевтичної хімії, Запорізький Аержавний меАичний університет, презиАент НВО "Фарматрон", Запоріжжя, Україна.

Шишкіна С. В., канА. хім. наук, аналітик НВО “Фарматрон”, Запоріжжя, Україна.

\section{Сведения об авторах:}

Кучеренко А. И., А-р фарм. наук, профессор,

зав. каф. фармацевтической химии, Запорожский

государственный меАицинский университет, вице-презияент

НПО «Фарматрон", Запорожье, Украина.
Хромылёва О. В., канА. фарм. наук, старший преподаватель каф. фармацевтической химии, Запорожский государственный медицинский университет, Украина.

Мазур И. А., А-р фарм. наук, профессор каф. фармацевтической химии, Запорожский государственный меАицинский университет, президент НПО “Фарматрон”, Запорожье, Украина. Шишкина С. В., канА. хим. наук, аналитик НПО "Фарматрон",

Запорожье, Украина.

Конфлікт інтересів: віАсутній.

Conflicts of Interest: authors have no conflict of interest to declare.

Надійшло Ао редакції / Received: 20.10.2016

Після Аоопрацювання / Revised: 06.12.2016

Прийнято Ао Аруку / Accepted: 30.12.2016 